\title{
The Albania Earthquake of 2019: Causes of Damage to the Buildings and Its Social Consequences
}

\author{
Darina Çoni (Kacollja) ${ }^{1, *}$, Albana Madhi \\ ${ }^{1}$ Faculty of Education, 'Aleksandër Xhuvani’ University, Elbasan 3001, Albania \\ ${ }^{2}$ Faculty of Economy, 'Aleksandër Xhuvani’ University, Elbasan 3001 Albania
}

Received September 5, 2021; Revised November 1, 2021; Accepted November 21, 2021

\begin{abstract}
Cite This Paper in the following Citation Styles
(a): [1] Darina Çoni (Kacollja), Albana Madhi, "The Albania Earthquake of 2019: Causes of Damage to the Buildings and Its Social Consequences," Civil Engineering and Architecture, Vol. 9, No. 7, pp. 2381 - 2388, 2021. DOI: 10.13189/cea.2021.090724.
\end{abstract}

(b): Darina Çoni (Kacollja), Albana Madhi (2021). The Albania Earthquake of 2019: Causes of Damage to the Buildings and Its Social Consequences. Civil Engineering and Architecture, 9(7), 2381 - 2388. DOI: 10.13189/cea.2021.090724.

Copyright $\odot 2021$ by authors, all rights reserved. Authors agree that this article remains permanently open access under the terms of the Creative Commons Attribution License 4.0 International License

\begin{abstract}
On 26 November 2019, the city of Durres in Albania was hit by an earthquake measuring 6.3 on the Richter scale with an intensity of $8-9$, killing 51 people in total. Some buildings were destroyed, causing fatalities, while many other buildings suffered serious damage but caused no fatalities. Many high-rise buildings up to 12 floors high sustained constructive and masonry damage. Most of the masonry damage was found in buildings built after 1991 and perceived by the general public to be safer. The damage to the residential high-rise buildings left many families homeless, and although approximately two years have passed since the quake, some of these families are still homeless. This study is based on 38 interviews with residents whose homes have become uninhabitable and with civil engineers who have worked in the construction sector. Additionally, 11 in-depth analyses that were carried out for 11 severely damaged objects were studied. This study aims to determine what caused the damage to these buildings. The causes ranged from unauthorised floor additions to lack of compliance with the best building codes during the design phase. It also shows the slow progress of reconstruction, particularly in the most severely damaged buildings. Furthermore, this protracted reconstruction period has led to social problems within families.
\end{abstract}

Keywords Earthquake, Reconstruction, Albania, Qualitative Study, Social Consequences

\section{Introduction}

Although earthquakes have been frequently recorded throughout history, seismology, the study of earthquakes, it is a relatively new science and is still in a formative stage [1]. The impact of natural disasters, such as earthquakes, floods, droughts, fires and tsunamis, can be intensified by historical, social, economic, political and environmental factors.

Whether a natural disaster becomes a humanitarian disaster depends a lot on the policies implemented to prevent or cope with its consequences [2]. Major disasters are characterised by significant loss of life and property, injuries and mental disorders [3]. The threat of earthquakes is exacerbated by the fact that they usually occur with little or no warning [4].

This qualitative study outlines the causes of the damage wrought by the MI 6.3 earthquake that struck the city of Durres on 26 November 2019 [5]. Additionally, it highlights the plight of the families affected by the earthquake. As Sehnbruch [6] points out, most countries, whether developed or developing, are not adequately prepared to deal with the traumatic and devastating consequences of natural disasters. During this particular earthquake, many buildings were destroyed, causing fatalities. However, less powerful earthquakes, which occur more frequently, can also be disastrous if they occur close enough to inhabited areas [7].

Construction has been going on for thousands of years. However, we have not learned until recently how to 
construct buildings that can remain undamaged after an earthquake [7]. Many buildings, particularly newer ones that were considered safe, were seriously damaged. The public believed that these palaces were supposed to have been built using the best European codes in the field of design and implementation. However, the 2019 earthquake challenged this view. Buildings that were constructed according to the latest building codes and those that were not will be distinguishable if an earthquake with an intensity above 8 occurs. Some of the buildings only sustained minor damage while others sustained severe damage. As you can see in figure 1, where some of these damages are shown. During this earthquake, 601 buildings and 2,431 houses [8] were severely damaged, and thousands of people were made homeless. Earthquakes can provoke or exacerbate crises and can reveal hidden forms of mismanagement and corruption [9].
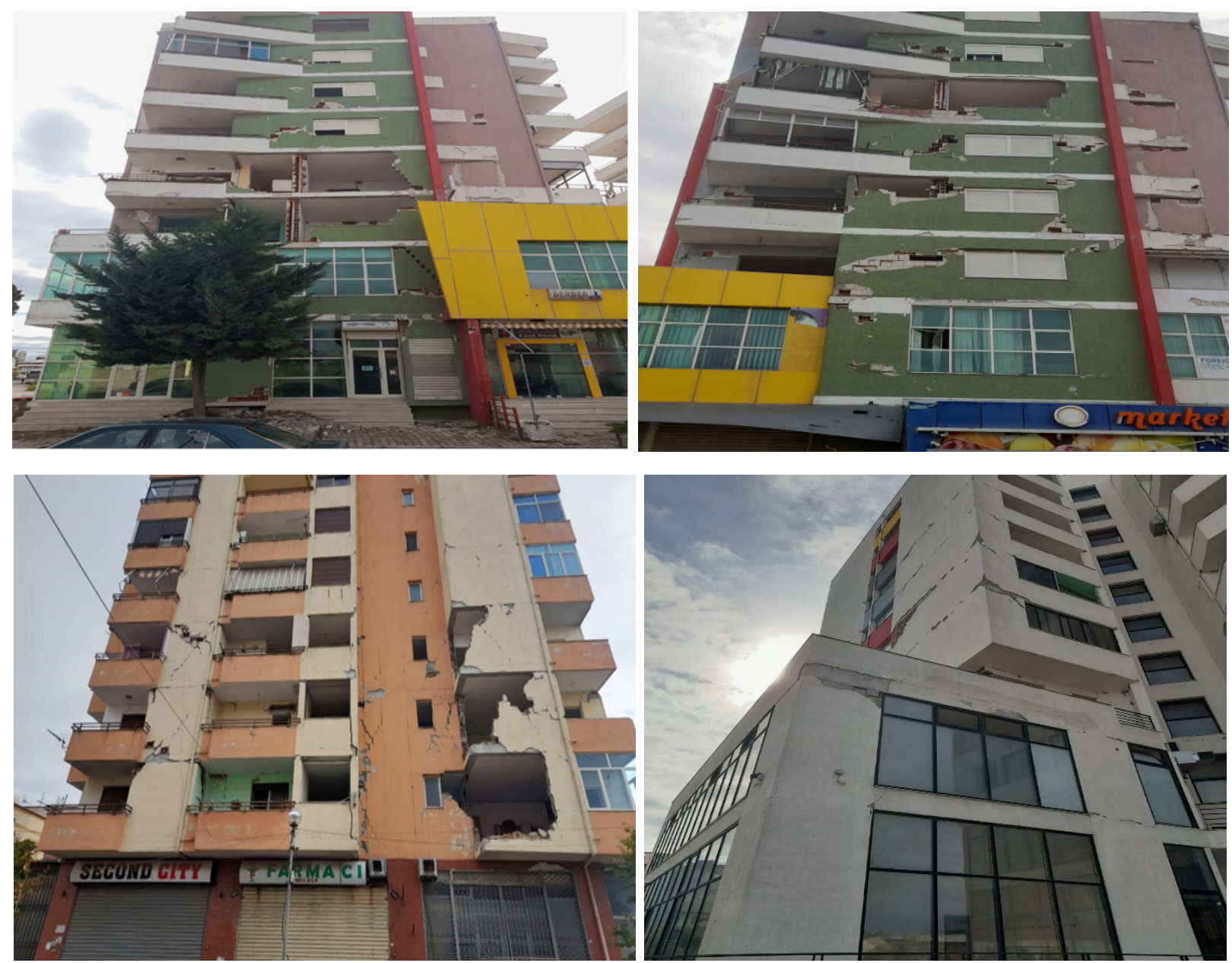

Source: Author

Figure 1. Residential buildings damaged by the earthquake 
This study will highlight some of the reasons that so many buildings were damaged during the earthquake. To study the causes of the damage, the buildings were separated into two categories.

The first category comprised buildings built before 1991 during the Socialist Communist period when the country isolated itself from the rest of the world, and the European building codes were no longer used. During this period, palaces with up to five floors prevailed and were built with supporting masonry or reinforced concrete construction.

The second category consisted of buildings constructed after the fall of the Communist regime. At that time, the best European codes began to be applied during both construction and the production of building materials. During this period, palaces with reinforced concrete construction were built on a massive scale. Despite being one of the most seismic areas in Albania, some of these buildings were built up to 20 floors high.

These causes must be studied in more detail so that different measures can be taken to construct buildings that are more likely to withstand future earthquakes. Benign [3] points out that gathering information on such events and determining their effects are of critical importance in organising social responses and creating programmes to improve and mitigate the impact of future disasters.

After each major earthquake, researchers have elucidated important seismic mechanisms associated with it, but uncertainty persists because of the diversity and complexity of earthquakes [10].

Recently, more attention is being paid to the long-term recovery phase, as social challenges (e.g., poverty and unemployment) can significantly impede the ability of earthquake survivors to return to their way of life. Reducing existing social weaknesses through economic development is a vital strategy for supporting the survivors [11]. This is now happening after the Durres, where reconstruction, particularly in severely damaged buildings, is progressing at snail's pace. The reconstruction of the less damaged buildings has been proceeding more quickly because the reconstructions were often done by the residents themselves, and the state financially compensated them later. Initially, a rapid reconstruction was promised due to the funds donated by international organisations immediately after the earthquake. The donors' conference held after the quake promised 1.15 billion euros for reconstruction. Earthquakes can attract more international aid than other types of disasters [12]. Once these funds are collected and invested in reconstruction, they can facilitate significant economic growth. When combined with weak economic policies and unpredictability, a natural disaster turns into an economic disaster [13]. Olshansky [14] states that any negative trends that existed before the catastrophe will usually worsen during the recovery period, including the economic downturn, social problems and emigration.
So far, there has been no transparency regarding the funds raised by donors, including those that have been invested in the reconstruction phase. In return, this has led to the loss of confidence of the people affected by the earthquake.

One of the disadvantages of this study is that we have not been able to access a large number of in-depth analyses by the Institute of Construction, not only for those buildings that have been severely damaged but also for those with moderate damage, where the causes of damage and the methods of reconstruction would be stated.

\section{Theoretical Framework}

Anthropologists consider that natural disasters can reveal weaknesses in the socio-cultural system; however, their approach singles out aspects of social processes rather than investigating the characteristics of the event [15]. Buildings exist to protect their occupants from harm, whether from natural or man-made causes, as well as from natural disasters such as earthquakes [16]. According to Katherine [17], earthquakes are natural phenomena that are a major concern for endangered areas, given the extraordinary ones, and impact all levels of society. Gliech [9] points out that strong earthquakes tend to leave deep traces in the collective memory of the affected country.

Furthermore, the most important long-term consequences of disasters are cultural and psychological in nature. Years, decades or even centuries later, artists, writers and filmmakers dedicate their works to the natural disasters that shaped the history of their country [9]. Earthquakes are unpredictable, but the casualties and damage that future earthquakes can cause are preventable [16]. As Beroza [18] points out, the best possible implementation of earthquake statistics is part of this issue, and a deeper understanding of the earthquake process is another. Each term has a different signature, and each one teaches us something new [19].

Additionally, taking the time to plan for post-disaster reconstruction is important to make the new buildings 'permanent' and as good as they can be. However, if the planning takes too long, this strategy will be ineffective [14].

\section{Methodology}

This study employed a qualitative methodology. When researchers have little information and need to rigorously explore a research problem by learning from participants, qualitative research is appropriate [20]. To begin with, we studied 11 in-depth analyses of severely damaged buildings, which had been performed by the Institute of Construction in Albania. Next, we conducted 38 
interviews to determine the other causes of damage, including the facilities that were damaged more easily as well as the reconstruction process and the social challenges faced by the affected families. The interviews focused on the city of Durres, near the epicentre of the earthquake.

We formed two frameworks within which the interviews were conducted. The first framework was for civil engineers working in the construction sector. The engineers were selected to discuss the causes of damage to civilian buildings during the quake. From their experience in this sector, they could give us a clearer picture of how the damage occurred.

The second framework included the people whose houses had been damaged by the quake, and they were selected to study the social consequences for these families as well as the reconstruction process.

Participants were randomly selected from within this framework. The questions were open-ended to allow the interviewees to describe their experiences in detail regarding the topics of interest. A total of 38 people were interviewed, 20 in the first group and 18 in the second. Each interview lasted approximately $35-45$ minutes. As the interviews were recorded, the participants were reassured that any information they shared would be kept confidential and that their names would be not mentioned to ensure anonymity. After the interviews were performed, they were transcribed and coded in vivo [21].

\section{Results}

The November 26 earthquake severely damaged many residential buildings; however, the causes of the damage were different. By analysing the 11 in-depth analyses carried out by the Institute of Construction, we found that all 11 severely damaged buildings had been designed according to the Albanian Design Codes of 1978, which were changed in 1989. These codes had not been updated with the European building codes. Additionally, the results showed that five buildings that were more than eight storeys high had been built after 1990 using the Albanian building codes; however, they should have been designed according to the European codes.

The main point that stood out from these analyses was that the structures were designed mainly according to the Albanian design conditions and did not respond to the seismic requirements of the European codes.

Furthermore, the interviews revealed several other ways that the buildings were damaged, including problems that had not been foreseen even by the civil engineers, who despite the problems they had encountered in their work, had not considered such eventualities.

On that note, one 60-year-old engineer disclosed that 'the situation was unforeseen for us as well, even though, at school, we were told that Durres was particularly prone to earthquakes.'

Another 45-year-old engineer mentioned that the building where they lived suffered serious damage from the earthquake. Construction is a complex sector, and many factors must be taken into account as to whether a building will withstand an earthquake. These factors include geological studies to see how much the soil holds and whether it needs reinforcement or not, seismic studies, and the construction process itself, which includes everything from the quality of the iron and concrete to the placement of bricks. If one of these phases is not properly implemented, the building is unlikely to withstand an earthquake.

A 50-year-old civil engineer stated, 'We did not think that the new facilities would have so many problems during the earthquake. Of course, our fear was for the old facilities or those built without permission but not for the new facilities.'

Additionally, the civil engineers interviewed expressed different opinions regarding the causes of the serious damage to buildings during the earthquake because it also depended on the damage to each building. Therefore, the buildings should be studied separately, and then, a detailed analysis should be conducted on the cause of damage based on the studies of the buildings to ensure that measures can be taken for their reinforcement and to determine whether the rules for the construction of new facilities should be changed so that this situation is never repeated.

One of the reasons that buildings were damaged during the earthquake was that they were often constructed without a building permit or even a construction project. Among other things, a 55-year-old engineer stated that the new facilities had serious problems because extra floors had often been added without a building permit. If they received a building permit in the municipality for an eight-storey building, and the project was done for eight floors, the construction companies would add another one or two floors illegally and would then apply for the legalisation process. I have heard stories of such buildings and have worked for such cases. Also, if you look at the buildings that collapsed and where there were victims, most of them did not have a building permit or had added extra floors without permission.

Regarding the question of how construction companies were able to build additional floors without permission and how they legalised these additional floors, he answered as follows:

'There is a law on legalisation - that all illegal objects would be legalised - and will apply to the offices that were opened for this purpose. After completing, the file for these objects would be legalised, meaning they would become legal and would be mortgaged. This law also included the additions of illegal buildings, allowing this agency to legalise and mortgage these additional floors. This led to a proliferation of floor extensions in buildings 
under construction, with the view that they would legalise them because their procedures were not as strict as those passed by the municipality for a building permit.'

Another engineer pointed out that illegal construction became normalised after the 1990s. In fact, not only multi-storey residential buildings but also buildings over eight floors high were often built without a building permit. When questioned how they could be built without a building permit, he emphasised that the state authorities were weak during this period, and they often had no power to stop such a construction.

'Even if these buildings were mortgaged later?' We asked.

'Of course, the law of legalisation came out, which legalised and mortgaged all illegal constructions. The problem with this law was that it came out sometime in 2006, but the timeline for including new constructions had been extended several times. Incredibly, discussions are underway to postpone the deadline again.'

Furthermore, another reason for the damage was the haphazard implementation of the European building codes during the construction. The Eurocodes were not updated with the Albanian building codes, which led to buildings being designed using both codes. The Albanian building code was mandatory, but whether the Eurocodes were used was left to the discretion of the designers.

Another engineer (42 years old) stated that the reasons why some buildings had problems, and some did not, stem from the fact the Albanian government allowed buildings to be designed using two different standards. They could be designed in accordance with the Albanian Design Codes that were approved in 1978. At that time, the highest building was five floors, and the codes had not been updated since then. On the other hand, buildings could also be designed following the Euro building codes, which were the best European codes for construction, especially in seismic areas. However, following the Eurocodes was not mandatory, and it was left to the designer to choose.

We asked why the designers did not choose to use the Eurocodes. He replied that construction according to the Eurocodes would be more costly because it would require more iron and larger columns. Buildings above eight floors in seismic areas cannot be built without concrete diaphragms, which are reinforced concrete walls. Consequently, this would increase the cost of building facilities by about 30 per cent.

Experienced builders tried to design buildings in accordance with the Eurocodes, while the engineers who were dealing with designs and who had just started to find clients to undertake the projects declared that they would reduce the cost of construction. Investors attracted by profit invariably chose these cheaper designers.

A 50-year-old engineer pointed out that the construction company where he worked for several years had built two buildings about 300 metres apart. Seismic, geological, iron and concrete studies were done and presented to the same companies, but the only factor they changed was the architect. For the first building, they had an old architect. However, for the second building, a new architect designed a 10-storey building without a reinforced concrete diaphragm. Subsequently, this building ended up suffering serious problems with the masonry.

A 67-year-old retired engineer stated that buildings should no longer be built using Albanian codes. From now on, only the Eurocodes should be used for new constructions, particularly in areas where earthquakes with an intensity up to 9 could be expected.

Additionally, the consequences affected old constructions built before the 1990s, even though they had a maximum of six floors. Some of these buildings had suffered severe damage, particularly in the columns. They were uninhabitable, and some of them had collapsed.

Regarding the causes of damage to buildings built before the 1990s, a 60-year-old engineer stated that buildings before the 1990s were designed for earthquakes of intensity measuring up to magnitude 8 , which meant that some buildings sustained serious column damage but did not collapse. These buildings probably remained standing because they were no higher than five storeys.

We asked him whether the new buildings constructed after 1991 were also built to withstand earthquakes with a maximum intensity of 8 .

He said that the only change that was made to the Albanian code was that facilities in the most endangered areas would be designed to withstand earthquakes with an intensity of magnitude 9. This resulted in no serious damage to the construction of these buildings built after 1991.

A 70-year-old engineer stated that the buildings built before 1991 suffered damage because they had never been renovated. Some of them were built in the 1970s and needed renovating, particularly the damaged parts. This particular engineer had seen that the columns were damaged before the earthquake; iron had leaked and rusted. With inadequate funding, they were reinforced and would react much better during the earthquake.

One of the causes of masonry problems was the non-implementation of enforcement codes, which makes the masonry prone to damage.

An engineer, about 30 years old, stated that minimal attention was often paid to the implementation codes during construction. When asked what the enforcement codes were, he pointed out that during construction, a 20 cm-thick strip made of iron and concrete had to be constructed in the middle of the masonry. This strip, according to the Albanian building codes, had to be connected to the building's columns. Additionally, reinforced concrete columns had to be constructed at the corners of the masonry to reduce possible damage to it.

A 35-year-old engineer opined that the engineers paid 
more attention to the construction of the reinforced concrete during construction, while often neglecting the masonry.

On the other hand, one of the causes of damage to the facilities was the lack of independent control measures during construction. Regardless of the codes, if all the applicable codes had been strictly enforced, the damage could have been much less.

A 65-year-old engineer stated that state control over the construction should have been stricter. These damages must strictly comply with all applicable codes. We asked whether the buildings are checked during construction. He replied that there is no independent institution that oversees the implementation of building codes during construction. Instead, it is the legal responsibility of the supervisor and the trustee of the facility. However, the supervisors and trustees are selected and paid for by the investor. They have no legal means to oppose the investor.

On that note, another engineer stated that the supervisor should be independent, and they should be elected and paid by the municipality. As an independent entity, the supervisor would be able to control the facility during construction and would ensure that the building codes are fully implemented.

Another problem that was addressed during these interviews was the reconstruction process. The respondents emphasised that the reconstruction process was progressing at a very slow pace.

A 53-year-old woman mentioned that the building she lived in had sustained serious damage and was categorised as DS 4 . When asked what the DS damages were, she replied that all buildings, after undergoing an inspection by construction specialists, were categorised from DS 0 , which is no damage, to DS 5 , which is very serious damage.

When asked where she lives, she said that she has rented a one-storey apartment.

'Do you get money from the state for rent?'

'Yes, we get the money, often late.'

When asked what is being done with her place, she replied that work has still not started and that she has been told that the project is underway. However, no one knows whether the building will be repaired or demolished and rebuilt.

Furthermore, when she was asked whether her apartment had been insured against earthquakes or fire, she replied that it had not and that her only hope was to have it rebuilt by the state.

A 40-year-old resident also spoke about his place. The masonry had been damaged by the earthquake, especially on the first three floors. However, during the inspection by the group set up by the municipality, it turned out that the building has deviated from verticality by about $40 \mathrm{~cm}$.

'How was it categorised?'

'As DS 5, and I do not know what will be done.'

'Are you interested in the municipality?'
'They are telling us that we will do the project, then they will intervene. We also hired a specialist at our expense, and they told us that the building has deviated from the centre even more. They also did a geological study and it turned out that the palace should have been made with pilots. Below the foundations that were made of slabs, pilots should have been constructed. In this way, we would not have the object removed.'

'Will the municipality rebuild the palace?'

'We do not know whether they will rebuild or reinforce it; they do not give us more detailed explanations. Some palaces have been demolished and are being rebuilt from scratch.'

'Did you have the apartment insured?'

'No, I did not have it insured; we hope that the state will rebuild them.'

In another building, a 65-year-old resident was told that the building had sustained only DS 2 damage. Thus, it was classed as habitable. They fixed the damage themselves, and the state compensated them.

'What about the compensation they gave you? How was it calculated?'

'Depending on the category of damage to the building, they also evaluated our payment. The same for each floor, even though some apartments had been damaged more than others, particularly those on the lower floors.'

Additionally, he stated that his apartment was uninsured. Another factor that was discussed with the people who came to the uninhabited building was the social problems they faced. For instance, quarrels between family members were some of the obstacles faced by families who suffered problems in the palaces that were damaged by the earthquake, particularly in the new palaces.

A man in his 50s stated, among other things, that 'after we calmed down from the earthquake and rented a house, the family quarrel started.' The main argument focused on who had decided to buy the apartment with this company. 'They all blamed me,' he continued, 'because I had decided that I knew little about the investors of this company, and they had built many mansions.'

On a similar note, a 60-year-old woman told us that once they had gotten over the initial shock of the earthquake, their life became more stressful. They had invested their life savings in their house, and with its destruction, it seemed that their lives had ended.

'What about your relationship with your husband and children during this time?'

'In the beginning, we fought over everything, we took out our stress on each other by shouting at each other. Now we have calmed down a little.'

'Have you re-entered your home?'

'No, but we have been told that the state will either fix our house or rebuild it from scratch. We want to rebuild it from scratch; it seems safer.' 


\section{Discussion}

This qualitative study has revealed the causes of damage to buildings during the 2019 Durres earthquake. The categorisation of the buildings was done according to the time period and not according to the building materials [22].

Durres is one of the most seismic areas in Albania, as Hovey [1] points out. No area of the world seems to be completely stable, but certain regions or areas are more prone to earthquakes than others.

Failure to comply with the optimal European building codes was one of the main reasons why newer buildings sustained damage. In Decision No. 68, dated 15.02.2001, 'On the approval of standards and technical conditions of design and implementation in construction works,' it is stated that for the design of constructions in seismic areas, the technical design conditions (KTP 2) of 1978 shall be applied [23]. Thus, no multi-storey buildings should be built with the ability to withstand strong earthquakes by using criteria set more than 40 years ago.

Additionally, the study shows that one of the main reasons for the damage is the poor functioning of state structures. These institutions should have adopted the best design codes available at the time. Having two different design codes allowed for the possibility of buildings to be designed using the 1978 codes.

The state failed to guarantee the quality of these works through independent mechanisms; as a result, it was the victims who suffered during the earthquake. Kulka [24] stated that buildings that are designed to consider the behaviour of an earthquake are more likely to successfully survive an earthquake.

Furthermore, the state's negligence has allowed several illegal constructions to be built without permits. This has led to many poor-quality buildings being constructed throughout Albania over several decades. Urban expansion accompanied by front development at disaster-prone zones and suburbs is becoming a critical issue in many towns in developing countries [25]. All cities and counties should adopt an overall plan to guide their future development, and it should include safety features to protect the community from natural disasters such as earthquakes, floods and fires [26].

The study has also shown that the reconstruction process has been neither fast nor transparent. In return, this has led to the state losing the trust of the people who lost their homes in the quake. The reconstruction and economic recovery of the affected regions take several years and often begin long after the event [9].

Another fact that has emerged from this study is that many residents' homes are not adequately protected against natural disasters. In case of disasters such as earthquakes, the state must expect to fund their reconstruction. But with disasters such as fires or floods, where the lack of the state will be greater, it will force residents to rebuild their homes if they can afford to.

\section{Conclusions}

The state must urgently intervene to increase the quality of construction, particularly in areas that are at high risk of earthquakes. The European building codes should be approved and updated and should not be applied alongside the Albanian codes during the design process. Furthermore, the supervision of a project must be independent of the investor; instead, it must be approved by the municipality or an association of supervisors. This will avoid conflict of interest, as a supervisor who is paid by the investor cannot control the construction process.

\section{REFERENCES}

[1] E. O. Hovey, "Earthquakes: Their Causes and Effects." Proceedings of the American Philosophical Society, vol. 48, no. 192, pp. 235-58, 1909. Accessed January 18, 2021. http://www.jstor.org/stable/984157

[2] L. Mayer, "Schooling System, Earthquakes and Beyond. The Chilean Experience of 2010". Iberoamericana. América Latina - España - Portugal, vol. 14, no. 55, pp. 147-162, 2014. Accessed January 29, 2021. https://doi.org/10.18441/ibam.14.2014.55.147-162.

[3] B. E. Aguirre, "Better Disaster Statistics: The Lisbon Earthquake" The Journal of Interdisciplinary History, vol. 43, no. 1, pp. 27-42, 2012. Accessed January 21, 2021. https://doi.org/10.1162/JINH_a_00337.

[4] M. Faizian NS H.R. Schalcher Department of Construction Engineering and Management, Federal Institute of Technology, ETH-Hönggerberg, CH-8093, Switzerland. M.H. Faber. Department of Structural Engineering, Swiss Federal Institute of Technology, ETH-Hönggerberg, CH-8093, Switzerland. http://webarchiv.ethz. ch/merci/ Publications/ Faizian paper.pdf

[5] Durresi earthquake of $26112019 \mathrm{ML}=6.3, \mathrm{Mw}=6.4$. https://www.geo. edu.al/newweb/? fq=november.

[6] K. Sehnbruch, A. Nurjk, W. Imilan, and C. Sanhueza, "Social Policy Responses of the Chilean State to the Earthquake and Tsunami of 2010." Latin American Perspectives, vol. 44, no. 4, pp. 24-40, 2017. Accessed February 20, 2021. https://doi.org/10.1177/0094582X1664 8955.

[7] A. G. Tarics, "Historical perspective: Earthquake! Are We Ready?" The Military Engineer, vol. 108, no. 699, pp. 90 92, 2016. Accessed March 22, 2021 http://www.jstor.org/stable/26357635.

[8] https://top-channel.tv/2020/01/11/termeti-shkaterroi-7905ndertesa-bilanci-tirane-u-demtuan-448-pallate-ne-durres-6 2-pallate/

[9] O. Gliech, "Introduction." Iberoamericana (2001-), vol. 14, no. 55, pp. 97-103, 2014. Accessed May 29, 2021. 
http://www.jstor.org/stable/24369230.

[10] Y. Ogata, "A Prospect of Earthquake Prediction Research." Statistical Science, vol. 28, no. 4, pp. 521-41, 2013. Accessed July 21, 2021. Google Scholar.

[11] M. Hayashi, Report. East-West Center, 2018. Accessed May 30, 2021. Google Scholar.

[12] D. Brancati, "Political Aftershocks: The Impact of Earthquakes on Intrastate Conflict." The Journal of Conflict Resolution, vol. 51, no. 5, pp. 715-43, 2007. Accessed May 27, 2021. https://doi.org/10.1177/00220027 07305234 .

[13] V. Albornoz and A. Daniela, "Social and Economic Consequences of the 1987 Earthquakes in Ecuador." Iberoamericana (2001-), vol. 14, no. 55, pp. 135-46, 2014. Accessed May 24, 2021.http://www.jstor.org/stable/24369 233.

[14] R. B. Olshansky, A. J. Laurie, and C. T. Kenneth, "Rebuilding Communities Following Disaster: Lessons from Kobe and Los Angeles." Built Environment (1978-), vol. 32, no. 4, pp. 354-74, 2006. Accessed May 03, 2021. https://doi.org/10.2148/benv.32.4.354.

[15] H. Takakura, "Local Agricultural Knowledge as Time Manipulation: Paddy Field Farmers after the Great East Japan Earthquake of 2011.” Asian Ethnology, vol. 77, no. $1 / 2$, pp. 257-84, 2018. Accessed May 30, 2021. https://www.jstor.org/stable/26604841.

[16] K. Baldridge, "Disaster Resilience: A Study of San Francisco's Soft-Story Building Problem." The Urban Lawyer, vol. 44, no. 2, pp. 465-92, 2012. Accessed May 29, 2021. http://www.jstor.org/stable/41638090.

[17] A.K.T. Meza, A. R. Ch. Sandra, and E. A. E. Cedeno, "Social resilience: earthquake consequences to an intense" International Research Journal of Management, IT \& Social Sciences, vol. 4, no. 1, pp. 24-31, 2017. https://sloap.org/journals/index.php/irjmis/article/view/435
[18] G. C. Beroza, "How Many Great Earthquakes Should We Expect?" Proceedings of the National Academy of Sciences of the United States of America, vol. 109, no. 3, pp. 651-52, 2012. Accessed July 01, 2021. https://doi.org/10.1073/pnas.1120744109.

[19] A. Bapat, "Disaster Management Plans in View of Recent Earthquakes." Current Science, vol. 98, no. 10, pp. 1287 88, 2010. Accessed June 4, 2021. Google Scholar.

[20] S. Merriam and E. Tisdell, 2015. Qualitative research: A guide to design and implementation. Jossey-Bass.

[21] J. Saldaña, 2016. Qualitative Coding the Manual Researcher. SAGE Publications Ltd.

[22] D. Bonowitz, "The Dilemma of Existing Buildings: Private Property, Public Risk.” Report. San Francisco Bay Area Planning and Urban Research Association (SPUR), pp 3-7, 2019. Accessed July 26, 2021. http://www.jstor.org/stable/ resrep22921.3.

[23] Botim i Qendrës së Publikimeve Zyrtare (BQPZ): Fletore zyrtare, nr 10 viti 2001. https://qbz.gov.al/eli/fz/ 2001/10/be45eb8b-a16b-47e6-837c-cb26ff3b4f25

[24] F. Kulka, "Concrete Buildings in Earthquakes." The Military Engineer, vol. 66, no. 430, pp. 116-17, 1974. Accessed July 26, 2021. http://www.jstor.org/stable/44572 521.

[25] O. Tiafack and A. Mbon, "Urban Growth and Front Development on Risk Zones: GIS Application for Mapping of Impacts on Yaounde North Western Highlands, Cameroon." Current Urban Studies, 5, pp. 217-235, 2017. DOI: $10.4236 /$ cus.2017.52013.

[26] L. Tam, L. Johnson, K. Exon-Smith, and J. Metwalli, "Safety First: Improving Hazard Resilience in the Bay Area." Report. San Francisco Bay Area Planning and Urban Research Association (SPUR), pp. 20-27, 2020. Steen K., Ed. Accessed August 5, 2021. http://www.jstor.org/stable/resrep26073.6. 